\title{
Needs Analysis of Junior High School Teachers at Kecamatan Hamparan Perak, Deli Serdang
}

\author{
Muhammad Rizki Syahputra ${ }^{1}$, Darwin ${ }^{2}$, Salman Bintang ${ }^{3}$ \\ Master of Education Administration, State University of Medan, Indonesia ${ }^{1}$ \\ State University of Medan, Indonesia ${ }^{2,3}$ \\ \{muhammadrizkisyahputra08@gmail.com ${ }^{1}$ \}
}

\begin{abstract}
This research aims to determine the need for analysis of junior high school teachers in the Kecamatan Hamparan Perak, Deli Serdang. Analysis of teacher needs is done by analyzing, 1) Analyze the actual condition map of the number of teachers based on junior high school subjects in the Kecamatan Hamparan Perak, Deli Serdang, 2) Analyzing the map needs of the ideal teachers based on the middle school subjects in the Kecamatan Hamparan Perak, Deli Serdang, 3) Analyzing the shortage of state junior high school teachers needed based on the subjects in the Kecamatan Hamparan Perak, Deli Serdang, 4) To analyze the solution to the number of disadvantages of junior high school teachers in the Kecamatan Hamparan Perak, Deli Serdang. The type of research used is a necessity analysis with a qualitative approach. This research was conducted in the state Junior high School in the Kecamatan Hamparan Perak Deli Serdang from July to October. Data collection techniques is using interview methods, documentation and observation studies. The results showed that 1) the actual map of the number of teachers based on junior high school subjects in the Kecamatan Hamparan Perak, Deli Serdang amounted to 61 teachers, 2) Map of the ideal teachers ' needs based on junior high school in the Kecamatan Hamparan Perak, Deli Serdang amounted to 91 teachers, 3) Shortage of state junior high school teachers needed based on the subjects in the Kecamatan Hamparan Perak, Deli Serdang amounted to 31 teachers. 4) Solution of fulfillment of the number of disadvantages of junior high school teachers in the district of the Kecamatan Hamparan Perak, Deli Serdang by reporting data of DAKL shortage of teachers to the district Education Office of Deli Serdang and to recruitment of honorary teachers for the subjects That there is a vacancy in the number of teacher subjects with funds from the School operational Assistance.
\end{abstract}

Keywords: Needs Analysis, Junior High School Teacher

\section{Introduction}

Teachers are resources that determine the success of national education development, the success of the education process depends on the role of teachers. Guru is one element of education stakeholders who play a leading role in educational institutions, the role of teachers in improving the quality of education can not be ignored as the teacher has a central role and in the success of national education.

The teacher's position needs to get attention like the needs and disadvantages of teachers who happen to each school. Analysis of teacher needs as a process to determine the number of teachers needed by the school, analysis of teachers ' needs to ensure that teachers ' needs are 
met. The conditions that occurred in some schools today have an excess number of teachers and there is a school that is still lacking in teachers. This is in line with the opinion of Engkoswara and Komariah suggests that one of the purposes of planning is to ensure the achievement and the use of resources efficiently, effectively, fairness and sustainable, the resources in the mean of course human resources, learning resources, curriculum or facilities [1].

Analysis of teacher needs is done in order to know the number of teachers ' needs in the future so that it can be used as a reference or guideline in determining the number of teachers needs. Analysis of the needs of teachers to avoid the proportion of the number of teachers is too much compared to the number of teachers needed, so that the government does not spend too much budget for teacher salaries.

The problem of this teacher's needs occurred in the district of Perak, Deli Serdang District, the Perak expanse of Deli Serdang District is one of 22 districts in Deli Serdang Regency. In Kecamatan Perak, there are 3 junior high schools. The lack of inaccuracy of teachers in Deli Serdang district is seen as an excess of the teacher in the state Junior high School, the District of Serdang. The needs of junior high school teachers in the sub-district, Deli Serdang District, 73 teachers, the existence of junior high school teachers in the Kecamatan Perak region of Deli Serdang, 56 teachers and disadvantages of junior high school in the district 19 teachers.

The availability of adequate teachers is the key to the sustainability of the teaching and learning process in every institution, the problem is that the spread of teachers that do not evenly impact the needs of teachers, the existence of teachers and Lack of teachers in several subjects that took place in junior high school in the district of Perak region Deli Serdang District.

Lack of the accuracy of the Master of State Junior high School in the district of Deli Serdang Regency has resulted in an excess of teachers in the schools and there is shortage of even vacancies in other schools. The unavailability of certain teacher of subjects, the limitations of central and local governments in the provision of teachers' quota in the recruitment process of civil servants and limited number of teachers graduates of certain subjects is one of the causes a certain subject void. Schools lacking a teacher's subjects indicated that the planning and distribution of the teacher's subjects had not been well done. The teacher's energy planning directs the management of teachers for the better, and also balances the teacher's need for teacher demand with a teacher supply.

The shortage of teachers will impede the implementation of quality improvement and equitable education programs, the teacher's deficiency will result in the cause of task for the teacher and otherwise excess teacher means the financial waste of the State and source Human resources. Besides, the efforts of the use of existing teachers is felt less effective due to the accuracy of teachers who are not good. This is reflected in the fact that there is a shortage of teachers in a school and an excess of teachers in other schools.

The need for teachers who are not met between supplies and demand will impede the learning process in school, lack of teachers in school indicated that the analysis of teacher needs has not been well patterned, so that the research is very Important for the purpose of obtaining an overview of how the business meets the needs of junior high school teachers in the district in the Perak region of Deli Serdang District, especially in the education office of Deli Serdang District.

\section{Teacher Needs Analysis}

Analysis is the process of solving a complex problem into small parts so that it can be easier to understand. Etymologically, the word analysis comes from the English language analysis which means careful examination. Meanwhile, the analysis is a thinking activity to 
describe a whole as a component so that it can recognize the signs of components, contact each other and function respectively in one whole Integrated [2].

The above opinion gives the idea that the analysis summarizes a large amount of data that is still raw into the information that can be interpreted. Categorisation or separation of the relevant components or parts of a data set is also a form of analysis used, all of which seeks to illustrate certain patterns consistently in the data so that The results can be learned and translated in a simple and meaningful way. The need for that is a gap between what is now with how it should be. If viewed in the context of education, the necessity is everything that can support all things that can create the process of education well. Both in the needs of teachers, infrastructure, curriculum, or other educational facilities that are able to influence the educational activities [3]. The needs of teachers is a reflection on the demands of the use of professional services teachers to provide education services to the students at the education institution of the teacher's school. Teachers ' need to provide certain education services must meet certain requirements ensuring that the service is demanded in accordance with the expectations of the user. The requirements that are expected are crucial because the education organizer demands a professional skill of the teacher who not everyone can have it [4].

Based on the above, it can be said that teachers are needed in order to create quality educational outcomes. But in fact in the field, the needs of teachers become problems facing the current education. Before planning the needs of teachers, there needs to be the creation of basic assumptions and special assumptions, the average population of migration, form of government, politics, economic organization, while the special assumption is an assumption centered on local conditions.

\section{Human Resource Planning}

Human Resource planning is a process that organizations use to ensure that the Organization has the right amount of manpower, available the right type of workforce, at the right time, at a position or place The place and do the proper work [5]. Furthermore, planning is the function of manager which involves the selection from alternatives of aobjectives, policies, procedures and programs. It means that planning is a manager's function that relates to choosing the objectives, policies, procedures, programs, and alternatives that exist [6].

Furthermore, it is a systematic and continuous process in analyzing the needs of the organization of human resources in a condition that is always changing and developing policies to the organization's long-term plan [7]. Human resource planning is the first function and should be implemented in the organization. Human resource planning is the specific measures taken by management to ensure that the appropriate employees are available to occupy various positions, and the right employees at the right time [8].

The various understandings that have been outlined can conclude that human resource planning is a systematic planning in terms of the need and provision of human resources that meet the requirements/qualifications to occupy various positions, which is useful to anticipate the shortage of human resources for the organization in the future, so that an organization will have the right amount of manpower, working at the right time, and Doing the right job.

\section{Methodology}

Research analysis needs of junior high school teachers in the sub-districts of Deli Serdang District type qualitative research. According to Creswell in Darmadi qualitative research is a 
study based on a methodology that investigates a social phenomenon and human problems. In qualitative research researchers made complex depictions, examined written or oral words, attitudes, detailed reports, or documentation from respondents or subjects that were subject to study and studied in a natural and described situation in the form of research reports [9].

The location that was used as a research site is junior high School in the Kecamatan Perak District Deli Serdang. The time of research started in July expires October 2019 until the data obtained saturated. Saturated data is a term to describe the data gained when the data source provides similarity to information or similarity of data. The subject in this study is the informant or the person providing the information needed in the collection of research data. The subject of research in this research is the perpetrators of both directly and indirectly involved in the analysis of the needs of junior high school teachers in the district of the Perak region of Deli Serdang District. The subject of research is Kabid coaching and the demonstration of the Education office of Deli Serdang Regency and head of SMP Pendidikan in the sub-district of Deli Serdang Regency. In addition to the above subject, the data of the existence of junior high school teachers in Deli Serdang District Education Office is also used as a requirement for analysis.

As an initial informant is chosen Purposif, which understands the object of research that overwhelms the problem studied (Key informant). Further information is requested to the initial informant to show others who can provide information and then the information is asked to also show other people who can provide information, as well as so on. This is usually referred to as a snowball that is performed sequentially.

\section{Results and Discussion}

3.1 Map of Actual Number of Teachers Based on Junior High School in The Perak Region of Deli Serdang District

Based on the teacher DAKL SMP Negeri 1 subdistrict of the silver-level Deli Serdang District, DAKL teachers SMP Negeri 2 District of the silver expanse of Deli Serdang District and DAKL teachers SMP Negeri 3 sub-district in the district of Deli Serdang, map of actual conditions number of teachers Based on junior high school in the Sub-district of the Perak region of Deli Serdang, the total number of 61 teachers, with details on the number of teachers of SMP Negeri 1 sub-district, Deli Serdang Regency 35 Teachers, number of teachers The silver expanse of Deli Serdang Regency 20 teachers and the number of teachers of SMP Negeri 3 sub-district Perak District Deli Serdang 6 teachers.

Based on the results of the study can be concluded that the actual condition map of the number of teachers based on junior high school in the Sub-district of the Perak region of Deli Serdang Total 61 teachers, with details of the number of teachers The silver expanse of Deli Serdang Regency 35 Teachers, the number of teachers of SMP Negeri 2 sub-district Perak District Deli Serdang 20 teachers, and the number of teachers of SMP Negeri 3 subdistrict of the district of Deli Serdang 6 teachers.

3.2 Map of Ideal Teacher Needs Based on The Public Junior High School in The Perak Region of Deli Serdang District

Based on the implementation guidelines for the needs of the teachers of the Ministry of Education and Culture, Directorate General of Teachers and education year 2018, map of the ideal teacher needs based on the subjects in the District Junior high School overlays Regency of 
Deli Serdang The total number of 91 teachers. With details needs of SMP Negeri 1 sub-district Perak District Deli Serdang amounted to 48 teachers, the need of SMP Negeri 2 sub-district of the regency of Deli Serdang, a total of 26 teachers and junior high School 3 sub-districts in Deli Serdang A total of 17 teachers, in the form of tables and graphs are described below.

Based on the results of research can be concluded that the map needs an ideal teacher based on the middle school subjects in the sub-district of the Perak region Deli Serdang Total number 91 teachers. With details of teachers ' needs in SMP Negeri 1, the Kecamatan Perak district of Deli Serdang amounted to 48 teachers, the needs of teachers in SMP Negeri 2 sub-districts of Deli Serdang District amounted to 26 teachers, and the needs of teachers at SMP Negeri 3 subdistrict Overlays The Perak Deli Serdang District amounted to 17 teachers.

3.3 Shortage of state junior high school teachers needed based on the subjects in the Perak expanse of Deli Serdang District

Based on the implementation guidelines for the needs of junior high school teachers, Ministry of Education and Culture Directorate General of Teachers and education year 2018 the ideal teachers and data of existing teachers based on the subjects in the junior high School of the Sub-district in the region of Deli Serdang District, then the number of shortages of teachers needed based on the subjects The district of Perak, Deli Serdang District. State Junior High School in the Sub-district of Deli Serdang District lacked 31 number of teachers with details of shortage of teachers in SMP Negeri 1 sub-districts of Deli Serdang district amounted to 14 teachers, lack of teachers in SMP Negeri 2 sub-districts The Perak Deli Serdang District amounted to 6 teachers and lack of teachers in SMP Negeri 3 sub-district of Deli Serdang District amounted to 11 teachers.

Based on the results of the study can be concluded that the shortage of state junior high school teachers needed based on the subjects in the district of Perak region of Deli Serdang Total 31 teachers. With details of the shortage of teachers in SMP Negeri 1 sub-districts of Deli Serdang District amounting to 14 teachers, shortage of teachers in SMP Negeri 2 sub-districts of Deli Serdang District amounted to 6 teachers, and lack of teachers in SMP Negeri 3 subdistrict. The silver overlay of Deli Serdang district amounted to 11 teachers.

\subsection{Fulfilment solution for total shortage of public junior high School in the Perak region of Deli Serdang District}

Based on the results of the study can be concluded that the solution to fulfill the number of disadvantages of junior high school teachers in the sub-district of Deli Serdang District as in SMP Negeri 1 sub-district of Deli Serdang District reported deficiency data The number of teachers to the Education office of Deli Serdang District and to conduct the recruitment of honorary teachers for the subjects that there is a vacancy with the cost of the school Operational Assistance Fund, solution for the number of lack of teachers in SMP Negeri 2 The Perak border district of Deli Serdang District reports the lack of the number of teachers to the district Education Office of Deli Serdang and the recruitment of honorary teachers for the subject of vacancy with the cost of the grants School operations and principals of SMP Negeri 2 in the district of the Perak district of Deli Serdang entered into teaching to fulfill the number of teachers lacking in IPS at SMP Negeri 2, The fulfillment of the number of shortage of teachers in SMP Negeri 3 sub-districts of Deli Serdang District reported that the data for the shortage of teachers to the district Education Office of Deli Serdang and recruitment of honorary teachers for the subjects Vacancy with the cost of the school's Operational Assistance Fund. 


\section{Conclusion}

Based on research conducted in junior High School (SMP) state in the district of Perak expanse of Deli Serdang Regency can be taken into the following conclusions:

1) Map of actual conditions of the number of teachers based on junior high school subjects in the district of Deli Serdang District Perak amounted to 61 teachers. That the actual condition of the number of teachers of SMP Negeri 1 sub-district of Deli Serdang Regency amounted to 35 teachers, map of actual conditions of the number of teachers based on the subjects in SMP Negeri 2 sub-district in the district of Deli Serdang, 20 teachers and The actual map of the number of teachers based on the subjects in SMP Negeri 3 sub-district of the district of Deli Serdang is 6 teachers,

2) Map of ideal teachers ' needs based on junior high school in the district of Perak region Deli Serdang amounted to 91 teachers. That the total needs of the teachers are ideal based on the subjects in SMP Negeri 1 sub-district in the district of Deli Serdang, amounting to 48 teachers, the number of ideal teacher needs based on the subjects in junior high School 2, Kecamatan Perak Deli Serdang District amounted to 26 teachers and number of ideal teachers ' needs based on the subjects in SMP Negeri 3 sub-districts of the district of Deli Serdang, 17 teachers,

3) Shortage of state junior high school teachers needed based on eye clumps In Deli Serdang District, a total of 31 teachers. Lack of teachers in SMP Negeri 1 sub-district Perak District Deli Serdang amounted to 14 teachers, shortage of teachers in SMP Negeri 2 sub-districts of Deli Serdang District amounted to 6 teachers and lack of teachers in SMP Negeri 3 subdistrict, Perak Deli Serdang Regency amounted to 11 teachers,

4) solutions for the number of shortcomings in the District Junior high School in the Perak region of Deli Serdang District. In fulfilling the lack of teachers in SMP Negeri 1 sub-district of Deli Serdang District reported that the data was lacking in the teachers to the district education office in Deli Serdang and to undertake the recruitment of honorary teachers for the subjects.

There is a vacancy in the number of teacher subjects with funding from the School operational Assistance (BOS). Solution SMP Negeri 2 Sub-district Perak District Deli Serdang in fulfillment of the lack of the number of teachers in SMP Negeri 2 sub-district of Recruitment of honorary teachers for the subjects with funding from the school's operational Assistance (BOS). But not all subjects that there is void the number of teachers in fulfill with an honorary teacher only a few subjects, this happens because the funding from the School operational Assistance (BOS) is insufficient if the funds to the honorary teachers. Solutions SMP Negeri 3 sub-district Perak District Deli Serdang in fulfillment of the lack of the number of teachers in the state junior high School 3 sub-districts of Deli Serdang by reporting data Kekuranagn the teacher to the Education office of Deli Serdang District and Add hours to the teachers to fulfill subjects that lack the number of teachers available in SMP Negeri 3 sub-districts of Deli Serdang Regency, as well as hiring honorary teachers for subjects That there is a vacancy in the number of teacher subjects with funds from the School operational Assistance (BOS).

\section{References}

[1] Engkoswara dan Komariah, Aan. Administrasi Pendidikan. Bandung: Alfabeta (2012).

[2] Komaruddin. Manajemen Pengawasan Kualitas Terpadu. Jakarta: Rajawali (2000). 
[3] Pidarta, Made. Perencanaan Pendidikan Partisipatori dengan Pendekatan Sisitem. Jakarta: Rineka Cipta (2005).

[4] Hartati, Sukirman. Manajemen Tenaga Pendidikan, Yogyakarta (2011).

[5] Kaswan. Manajemen Sumber Daya Manusia: Untuk Keunggulan Bersaing Organisasi, Yogyakarta: Graha Ilmu (2012).

[6] Samsudin, Sadili. Manajemen Sumber Daya Manusia. Bandung: Pustaka Setia (2010).

[7] Syofyandi, Herman. Manajemen Sumber Daya Manusia. Yogyakarta: Graha Ilmu (2013).

[8] Syofyandi, Herman. Manajemen Sumber Daya Manusia. Yogyakarta: Graha Ilmu (2013).

[9] Darmadi, Hamid. Metode Penelitian Pendidikan dan Sosial, Bandung: Alfabeta (2013). 